\title{
OCCULT HEPATITIS B VIRUS INFECTION IN PATIENTS WITH CHRONIC LIVER DISEASE DUE TO HEPATITIS C VIRUS AND HEPATOCELLULAR CARCINOMA IN BRAZIL
}

\author{
Fernanda BRANCO ${ }^{1}$, Angelo Alves de MATTOS ${ }^{1}$, Gabriela Perdomo CORAL ${ }^{1}$, \\ Bart VANDERBORGHT ${ }^{2}$, Diogo Edele SANTOS ${ }^{1}$, Paulo FRANÇA ${ }^{2}$ and \\ Cláudio ALEXANDRE
}

\begin{abstract}
Background - The prevalence and consequences of occult HBV infection in patients with chronic liver disease by HCV remain unknown. Aims - To evaluate the prevalence of occult HBV infection in a population of HCV-infected patients with hepatocellular carcinoma. Methods - The serum samples were tested for HBV DNA by nested PCR and liver tissue analysis was carried out using the immunohistochemical technique of $66 \mathrm{HBsAg}$-negative patients: 26 patients with chronic hepatitis by HCV (group 1), 20 with hepatocellular carcinoma related to chronic infection by HCV (group 2) and 20 with negative viral markers for hepatitis B and C (control group). Results - Occult HBV infection was diagnosed in the liver tissue of 9/46 (19.5\%) HCV-infected patients. Prevalence of occult B infection was evaluated in the $\mathrm{HCV}$-infected patients with and without hepatocellular carcinoma, and there were seven (77.7\%) of whom from group 2 , conferring a $35 \%$ prevalence of this group. No serum sample was positive for HBV DNA in the three groups. Conclusion - Occult infection $\mathrm{B}$ is frequently detected in liver tissue of $\mathrm{HCV}$-infected patients, especially in cases of hepatocellular carcinoma. However large studies are needed to confirm that co-infection could determine a worse progress of chronic liver disease in this population
\end{abstract}

HEADINGS - Carcinoma, hepatocellular. Hepatitis B virus. Hepatitis C virus. Liver diseases.

\section{INTRODUCTION}

Hepatitis B and C viruses (HBV and HCV) are the main etiological agents of chronic hepatitis related to the emergence of liver cirrhosis and hepatocellular carcinoma $(\mathrm{HCC})^{(14,26)}$

Despite careful investigations into the etiological factors for chronic liver disease, in 5\%-10\% of cases no etiological factor is detected ${ }^{(27)}$. However, this index may be smaller if molecular tests are performed in search of occult infection with HBV in this population ${ }^{(2,4)}$

By occult infection with HBV it is meant an infection in which there is positivity for the viral DNA in the serum or liver tissue, as diagnosed by hybridization techniques or PCR or by the presence of HBV antigens in liver tissue by immunohistochemistry, despite absence of HBsAg in the serum. Described many years ago, even before the finding of $\mathrm{HCV}^{(6,19)}$, the infection's true prevalence, physiopathogeny and clinical impact are still a matter of debate $^{(1,2,5,7,11,23)}$

The prevalence of co-infection, is about $15 \%-30 \%$, and $40 \%-50 \%$ when serum and liver tissue are tested, respectively $(7,9,13,15,36)$ and differs with sensibility of test used.

The importance of an association between HBV and HCV lies in the fact that although HBV viral load in occult infection is often low, a greater likelihood of progression to cirrhosis and to HCC is observed when these patients are compared with those infected only with $\operatorname{HCV}^{(7,9,36,37)}$. 
Identification of the HBV genome has been reported in liver tumors of patients who are $\mathrm{HCV}$-positive and $\mathrm{HBsAg}$-negative in the serum ${ }^{(32,34,37,38)}$. The rate of occult infection in HCV-positive patients with $\mathrm{HCC}$ can be as high as $76 \% \%^{(24)}$.

The presence of viral DNA integration in the cells of nontumoral liver tissue ${ }^{(34,37)}$ in patients with HCC suggests that the genomic integration precedes the development of neoplasia. Thus, chronic infection with HBV may be correlated with the emergence of HCC even in the absence of liver cirrhosis ${ }^{(38)}$.

The consequences of occult HBV infection in patients with chronic liver disease by HCV remain unknown. Despite evidence that co-infection may accelerate the progress to liver disease ${ }^{(9,41)}$, be related to the emergence of $\operatorname{HCC}^{(34,37,38)}$, and adversely influence the response to HCV treatment ${ }^{(7,9,13,41)}$, other studies show that occult infection does not interfere with the natural history of the disorder in this population ${ }^{(12,15,16,22)}$.

The present study was designed to evaluate the importance of occult $\mathrm{HBV}$ in patients with chronic infection by $\mathrm{HCV}$ and hepatocellular carcinoma in Brazil.

\section{METHODS}

From February 2003 to May 2004, serum and liver tissue samples from 66 patients, coming from the "Complexo Hospitalar Santa Casa de Porto Alegre", in Porto Alegre, RS, Brazil, were prospectively assessed.

The patients were divided in three groups: group $1-26$ consecutive patients with chronic infection by HCV, who were in pre-treatment evaluation in the Hepatology Unit or during hospitalization for liver transplantation; group $2-20$ patients with chronic infection by HCV and HCC, evaluated consecutively at admission for liver transplantation, surgical resection of tumor, or liver nodule biopsy, and control group -20 patients with negative hepatitis $\mathrm{B}$ and $\mathrm{C}$ viral markers in the serum, selected for cholecystectomy.

The patients in groups 1 and 2 did not present concomitant causes of chronic liver disease. Autoimmune hepatitis, hemochromatosis, alpha-1-atitrypsin deficiency, glycogen storage disease were excluded by negative results of anti-nuclear, anti-smooth muscle and anti-mitochondrial antibody and by normal values of $\alpha-1$ antitrysin, transferrin saturation and ceruloplasmin. The patients included in the study had no history of alcohol abuse, did not use potentially hepatotoxic drugs, and were not HIV-infected (measured by third-generation enzyme immunoassay, Cobas, Roche).

Inclusion criteria to select patients of group 2 were the following: two dynamic imaging techniques (computerized tomography and magnetic resonance imaging) showing focal liver lesion with arterial hypervascularization, or one of these positive imaging method associated with alpha-fetoprotein level above $400 \mathrm{ng} / \mathrm{mL}^{(8)}$. The diagnosis of HCC was confirmed by histological analysis in all cases.

Blood samples were collected at the same time of liver biopsy collection, in patients of groups 1 and 2, by biopsy with ultrasonographic-guided and wedge-shaped needle during hepatectomy or liver transplantation and, in group 3, by wedge biopsy during cholecystectomy.

\section{Serum viral markers}

$\mathrm{HBsAg}$, total anti-HBc and anti-HBs were measured in duplicate by electrochemoluminescence (Elecsys 2010-Roche). Anti-HCV was detected by amplified electrochemoluminescence using a third generation technique (Vitros Eci, Johnson \& Johnson) as recommended by the manufacturers.

\section{Qualitative analysis of HCV by RT-PCR}

The HCV Amplicor ${ }^{\circledR}$ test of viral genome amplification was used (Roche Diagnostics Systems, Inc., Branchburg, NJ, USA) using reverse transcription polymerase chain reaction as recommended by the manufacturers and detection limit of 100 copies/mL.

\section{Quantitative analysis of HCV by RT-PCR}

Viremia was determined using the Amplicor HCV Monitor ${ }^{\circledR}$ test, version 2.0 (Roche Molecular System Inc., Branchburg, NJ, USA). The detection limit of the test was $600 \mathrm{IU} / \mathrm{mL}^{(33)}$.

\section{HCV genotyping}

$\mathrm{HCV}$ genotyping was determined as described by McOMISH et al. ${ }^{(29)}$, using the product of RT-PCR in restriction enzyme assay by the restriction fragment length polymorphism (RFLP) technique.

\section{HBV DNA by nested PCR}

It was performed in the Laboratory of Molecular Biology of the Hepatology Service of the "Hospital Universitário Clementino Fraga Filho" of the Federal University of Rio de Janeiro, RJ, Brazil using the "in house" technique. DNA was extracted with Qiamp DNA Blood Mini Kit (Qiagen GmbH, Hilden, Germany). B and $\mathrm{C}$ domains of polimerase was amplified in each DNA sample. In the first step an Outer PCR was a product of amplification, and in second assay an Inner PCR was the product of amplification. Limit of test detection was 200 copies $/ \mathrm{mL}$.

\section{Viral markers in liver tissue}

$\mathrm{HBV}$ antigens ( $\mathrm{HBsAg}$ and $\mathrm{HBcAg}$ ) were identified through primary antibodies (goat-anti hepatitis B surface antigen and rabbit-anti hepatitis B core antigen) and secondary antibody LSAB plus System (Dako). The immunologic signal of the presence of antigens was detected by a system based on streptoavidin-biotin complex HRP (Dako). Positive and negative controls were used in each session ${ }^{(12,17)}$.

\section{Histopathological analysis}

The samples were classified according to Metavir's classification ${ }^{(3)}$ staging was defined as F0 (no fibrosis), F1 (fibrosis limited to portal tract), F2 (fibrosis with septa), F3 (severe fibrosis) and F4 (fibrosis with septa delimiting nodules). HCC staging was performed according to the Japanese classification ${ }^{(25)}$.

The analysis was carried out in all samples by a pathologist unaware of the status of occult B virus infection.

\section{Ethical considerations}

All patients or their family members signed an informed consent before inclusion in the protocol. The project was approved 
TABLE 1. Characteristics of the patients

\begin{tabular}{|c|c|c|c|c|}
\hline Variables & $\begin{array}{c}\text { HCV } n=26 \\
(\%)\end{array}$ & HCV-HCC $\mathrm{n}=20(\%)$ & $\begin{array}{c}\text { Control } \mathrm{n}=20 \\
(\%)\end{array}$ & $P$ \\
\hline Age* & $49.6 \pm 10.8$ & $56.6 \pm 11.6$ & $51.9 \pm 18.2$ & 0.234 \\
\hline Gender** & & & & 0.062 \\
\hline Male & $11(42.3)$ & $14(70)$ & $7(35)$ & \\
\hline Female & $15(57.7)$ & $6(30)$ & $13(65)$ & \\
\hline Transfusion $* *$ & $15(53.8)$ & $13(65)$ & $4(20)$ & 0.008 \\
\hline Drugs $* *$ & $3(11.5)$ & $3(15)$ & $0(0.0)$ & - \\
\hline \multicolumn{5}{|l|}{ Laboratory tests* } \\
\hline $\operatorname{ALT}(\mathrm{IU} / \mathrm{L})$ & $82.69 \pm 50.46$ & $111.50 \pm 80.11$ & $34.15 \pm 11.68$ & $<0.001$ \\
\hline AST(IU/L) & $66.92 \pm 37.19$ & $128.40 \pm 95.81$ & $27.75 \pm 16.58$ & $<0.001$ \\
\hline $\mathrm{BT}(\mathrm{mg} / \mathrm{dL})$ & $1.108 \pm 1.294$ & $1.960 \pm 1.268$ & $0.720 \pm 0.438$ & 0.002 \\
\hline $\mathrm{BD}(\mathrm{mg} / \mathrm{dL})$ & $0.312 \pm 0.414$ & $0.735 \pm 0.656$ & $0.230 \pm 0.266$ & 0.002 \\
\hline $\mathrm{FA}(\mathrm{U} / \mathrm{L})$ & $83.42 \pm 29.28$ & $122.95 \pm 70.43$ & $99.10 \pm 58.86$ & 0.053 \\
\hline $\mathrm{TP}(\%)$ & $85.26 \pm 13.64$ & $72.10 \pm 12.67$ & $86.4 \pm 12.52$ & 0.005 \\
\hline Albumin $(\mathrm{g} / \mathrm{dL})$ & $4.26 \pm 0.575$ & $3.53 \pm 0.75$ & $4.04 \pm 0.60$ & 0.001 \\
\hline Platelets $\left(/ \mathrm{mm}^{3}\right)$ & $198.840 \pm 87.986$ & $112.350 \pm 63.499$ & $256.850 \pm 59.129$ & $<0.001$ \\
\hline \multicolumn{5}{|l|}{ Child-Pugh } \\
\hline A & $2(7.6)$ & $6(30)$ & & \\
\hline B & $0(0,0)$ & $9(45)$ & & \\
\hline C & $2(7,6)$ & $4(20)$ & & \\
\hline Without cirrhosis & $22(84.6)$ & $1(5)$ & & \\
\hline
\end{tabular}

Mean \pm SD; ANOVA test $=$ analysis of variance

by the Ethical Committee of the "Complexo Hospitalar Santa Casa de Porto Alegre".

\section{Statistical analysis}

The data were stored in the MS Access 2000 program and analyzed with resources of the SPSS 10.0 system (Statistical Package for Social Science).

The categorical variables were analyzed by Fisher's exact test with the complementary resource of adjusted residues analysis.

The quantitative variables were analyzed by ANOVA with a complementary resource for Tukey's multiple comparisons.

The level of significance used was $5 \%$.

\section{RESULTS}

\section{Characteristics of the patients}

Characteristics of the patients are shown in Table 1.

Concerning laboratory tests, while patients of group 1 were similar to those of the control group as regards liver function tests (bilirubin, prothrombin time and albumin), they showed higher levels of aminotransferases and lower levels of platelets. When bilirubin, prothrombin time and albumin levels of groups 1 and 2 were compared, chronic liver disease was observed to be more severe in group 2.

In 17 of 26 patients with chronic liver disease by HCV, there was evidence of one or both risk factors, and in $9 / 17$ $(52.9 \%)$ such factors occurred more than 20 years ago. In the 20 patients in the group with HCC, risk factors were present in 15 patients, in 14 of whom they occurred more than 20 years ago $(P=0.018)$.

\section{Detection of HBV markers}

The HBV DNA was not detected in the serum of any of the 66 patients evaluated.

Occult B infection was diagnosed by immunohistochemistry through the detection of HBV antigens (HBsAg and/or HBcAg) in liver tissue in $9 / 46(19.5 \%) \mathrm{HCV}$-infected patients and in $1 / 20(5 \%)$ patients of the control group. The HBsAg was detected in isolation in liver tissue of 7/46 HCV-infected patients, and in 2 cases in association with $\mathrm{HBcAg}$. No patient presented $\mathrm{HBcAg}$ in isolation in tissue. In the patient of the control group, both markers were detected.

As we analyzed the prevalence of occult infection in the $\mathrm{HCV}$-infected population, we found that of the nine positive patients, seven $(77.7 \%)$ were in group $2, \mathrm{OR}=6.46 P=0.029$. These results confer to occult $\mathrm{B}$ infection a prevalence of $35 \%$ in patients with HCV and HCC (Table 2).

TABLE 2. Comparison of groups concerning immunohistochemistry

\begin{tabular}{lccccc}
\hline \multirow{2}{*}{ Groups } & $\mathbf{n}$ & \multicolumn{2}{l}{$\begin{array}{l}\text { Immunohistochemistry } \\
\text { (HBsAg and/or HBcAg) }\end{array}$} & OR (CI 95\%) & $\boldsymbol{P}$ \\
\cline { 3 - 5 } & & Positive & Negative & & \\
\hline 1 & 26 & 2 & 24 & $6.46(1.17,35.74)$ & 0.029 \\
2 & 20 & 7 & 13 & & \\
$1+2$ & 46 & 9 & 37 & $4.50(0.53,38.2)$ & 0.260 \\
Control & 20 & 1 & 19 & & \\
\hline
\end{tabular}

The presence of HBV antigens was tested in tumor tissue in 15 cases and in the non-tumor tissue in 20. The HBsAg was present in the tissue surrounding the tumor in seven cases, six in isolation and one concomitantly to $\mathrm{HBcAg}$. In tumor tissue, among the 15 cases evaluated the HBsAg was detected in 5 
cases, 4 of which in isolation and 1 in association with $\mathrm{HBcAg}$. No patient presented antigen in the tumor without showing it in the surrounding tissue (Figure 1).

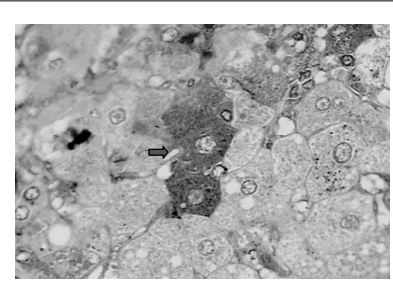

(a)

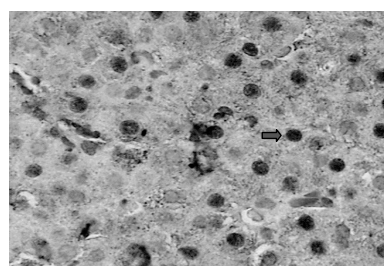

(c)

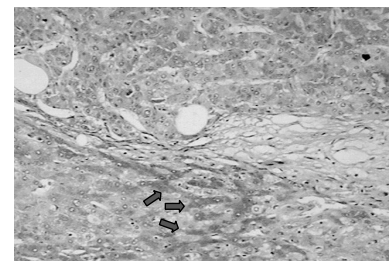

(b)

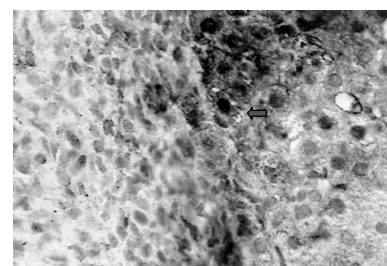

(d)
HBsAg in the cytoplasm of hepatocytes (a) tissue surrounding the tumor with HBSAg in the cytoplasm of hepatocytes (b) HBCAg in the nuclei of hepatocytes and $\mathrm{HBCAg}$ in the nucleus (d)

FIGURE 1. Detection of HBsAg and $\mathrm{HBcAg}$ by immunohistochemistry in liver tissue

When the $46 \mathrm{HCV}$-infected patients with or without occult $\mathrm{B}$ infection were compared regarding biochemical parameters, greater liver dysfunction was observed in the co-infected group (Table 3 ).

TABLE 3. Characteristics of $\mathrm{HCV}$-infected patients with and without HBV occult

\begin{tabular}{|c|c|c|c|}
\hline \multirow[b]{2}{*}{ Laboratory tests* } & \multicolumn{2}{|c|}{ HCV positive $(n=46)$} & \multirow[b]{2}{*}{$P$} \\
\hline & $\begin{array}{l}\text { Occult HBV positive } \\
(n=9)\end{array}$ & $\begin{array}{l}\text { Occult HBV negative } \\
(\mathrm{n}=37)\end{array}$ & \\
\hline Age** & 55,3 & 52 & 0.33 \\
\hline ALT & $81.11 \pm 50.13$ & $98.65 \pm 69.25$ & 0.480 \\
\hline AST & $100.44 \pm 62.62$ & $91.73 \pm 78.17$ & 0.758 \\
\hline Alkaline phosphatase & $118.11 \pm 34.44$ & $96.35 \pm 57.84$ & 0.287 \\
\hline Total bilirubin & $2.36 \pm 1.77$ & $1.26 \pm 1.13$ & 0.025 \\
\hline Direct bilirubin & $0.84 \pm 0.84$ & $0.41 \pm 0.45$ & 0.038 \\
\hline Prothrombin time (\%) & $67.89 \pm 12.73$ & $81.24 \pm 15.17$ & 0.019 \\
\hline Albumin & $3.46 \pm 0.55$ & $4.06 \pm 0.74$ & 0.030 \\
\hline Platelets & $97.333 .33 \pm 68.291 .65$ & $183.691 .89 \pm 82.505 .63$ & 0.006 \\
\hline
\end{tabular}

* Variables appear as means (standard deviation)
** Mann-Whitney test

When HCV-infected patients with and without coinfection were compared as regards probable time of $\mathrm{HCV}$ infection, 9 patients were found to be co-infected, 8 of whom evidencing the risk factors (blood transfusion and/or IV drug use), and in 7 they occurred more than 20 years ago
(87.5\%), as compared to 8 of the 24 patients (33.3\%) without co-infection and with risk factors more than 20 years ago. Therefore, the length of HCV infection was significantly greater in patients with occult $\mathrm{B}$ infection than in those without it $(P=0.013)$.

Among the nine HCV-infected patients co-infected with occult HBV, six $(66.6 \%)$ had markers of previous HBV infection. Five out of seven $(71.4 \%)$ patients with HCC and occult B infection also presented these markers in the serum (two anti-HBc-positive and three anti-HBc and anti-HBspositive), and in two cases no marker of previous exposure to HBV was found.

\section{HCV and occult infection}

$\mathrm{HCV}$ genotyping was assessed in 44 patients. Genotype 1 was present in 20 cases and genotypes 2 or 3 in 24 cases. Of the eight patients with HCV and occult B infection evaluated, genotype 1 was detected in four cases $(50 \%)(P=1.0)$. Of the 39 cases, mean viral load was $569.871 \mathrm{UI} / \mathrm{mL}(\mathrm{SD}=608.143$ and median $=311.000 \mathrm{UI} / \mathrm{mL})$ in patients without occult $\mathrm{B}$ infection and $222.293 \mathrm{UI} / \mathrm{mL}(\mathrm{SD}=325.403$ and median $=117.118)$ $P=0.119$ in patients with occult B infection.

Of the nine HCV-infected patients with occult B infection, eight showed a higher degree of activity (A2-A3), without attaining, though, a statistically significant difference as compared to patients without this type of infection $(P=0.23)$. Concerning liver fibrosis, all nine patients presented fibrosis degree between F3-F4, which was statistically significant as compared to the other patients without the infection $(P=0.007)$ (Table 4$)$.

TABLE 4. Comparison of degree of activity/fibrosis regarding immunohistochemistry (HBsAg and/or $\mathrm{HBcAg}$ )

\begin{tabular}{lccc}
\hline Metavir (n=46) & $\begin{array}{c}\text { Occult HBV }+(\%) \\
(\mathbf{n}=9)\end{array}$ & $\begin{array}{c}\text { Occult HBV }-(\%) \\
(\mathbf{n}=37)\end{array}$ & $P$ \\
\hline Degree of activity* & & & \\
A0-A1 & $1(11.1)$ & $14(37.8)$ & \\
A2-A3 & $8(88.9)$ & $23(62.2)$ & 0.235 \\
Degree of fibrosis* & & & \\
F0-F1-F2 & $0(0.0)$ & $18(48.6)$ & \\
F3-F4 & $9(100.0)$ & $19(51.4)$ & 0.007 \\
\hline
\end{tabular}

*Variables appear as frequencies (percentage), Fisher's exact test used

Of the seven patients with occult B infection in group 2, the tumor was well or moderately differentiated in three patient and poorly differentiated in other three. One case was not evaluated because of the presence of tumor necrosis. Among the 13 patients without occult infection, 6 presented well or moderately differentiated HCC, and 4, poorly differentiated. Two cases could not be evaluated due to lack of viable cells secondary to complete necrosis of the tumor following alcoholization bouts.

Of the 18 patients evaluated, the mean tumor diameter in the cases of occult HBV $(2.74 \mathrm{~cm})$ did not show a statistically significant difference $(P=0.96)$ as compared to patients with $\mathrm{HCC}$ without this infection $(2.70 \mathrm{~cm})$. 


\section{DISCUSSION}

In this study, we have investigated the prevalence of occult $\mathrm{HBV}$ infection in a population of $\mathrm{HCV}$-infected patients at different stages of the disease, from chronic hepatitis to hepatocellular carcinoma, and we compared the findings with those of patients without chronic liver disease and without markers of previous exposure to $\mathrm{B}$ or $\mathrm{C}$ viruses.

The absence of HBV DNA in the serum of the 66 patients evaluated could be accounted for by the low viremia present in patients with occult B infection ${ }^{(41)}$. Other factors to be considered are: the finding, in a longitudinal study ${ }^{(4)}$, that viremia may in some cases occur intermittently, greater HBV DNA concentration in liver tissue samples as compared to serum samples ${ }^{(2,6,9,23,37)}$ and the geographical distribution of HBV infection, which is low in our community $(0.4 \%)^{(39)}$.

In contrast, HBV DNA has been found in serum by PCR in $6.7 \%$ to $52 \%(13,15,16)$ of HBsAg-negative patients with chronic HCV infection, in $5 \%$ to $76 \% \%^{(7,10,30)}$ of patients with chronic liver disease of no defined etiology, and in $0 \%{ }^{(15)}$ to $15 \%{ }^{(21)}$ of healthy donors.

The prevalence of occult B infection in HCV-infected patients in the present study $(19.5 \%)$ was above the one reported by some authors $^{(9,12)}$ and below the percentages reported by others ${ }^{(21,28,36,38)}$, which can be as high as $76 \%{ }^{(24)}$. It should be highlighted that the latter studies used PCR for viral DNA detection, a technique which is more sensitive than immunohistochemistry ${ }^{(4,12)}$. It is not well established if failure to detect HBV antigens by immunohistochemistry in a few patients with occult $\mathrm{B}$ infection ${ }^{(9,28)}$ is solely related to low viral replication, or if variations in samples size and the presence of viral mutations may play a role in these results.

In the present study, detection of HBsAg in liver tissue was more frequent than detection of $\mathrm{HBcAg}$, suggesting that most patients were not in the replicative viral phase, which would be reflected by lower viremia. This finding is in agreement with other studies ${ }^{(7,20,30,31)}$ demonstrating that HBsAg is more sensitive than $\mathrm{HBcAg}$ in liver tissue.

Growing evidence suggest a high prevalence of occult $\mathrm{B}$ infection in $\mathrm{HCV}$-infected patients with $\mathrm{HCC}^{(4)}$. When HCVpositive patients with and without $\mathrm{HCC}$ are compared, the prevalence of occult infection is $48 \%$ to $76 \%$ in the first group and $30 \%-40 \%$ in the second ${ }^{(9,24,34)}$

The greater prevalence in this study of HBV antigens detected in patients with HCC could be ascribed to the role HBV may play in the hepatocarcinogenesis of patients with chronic HCV infection. This pathogenic synergism has been reported ${ }^{(37)}$.

In 4 of the $10(40 \%)$ patients evaluated here ( 3 patients with $\mathrm{HCV}$ and 1 patient of the control group), occult $\mathrm{B}$ infection was diagnosed in the absence of any serologic marker of B virus. The explanation for this finding may be in the fact that patients with occult B infection would be infected with low levels of viral particles incapable of stimulating the immune system to form its antibodies ${ }^{(28)}$, or that, following acute infection patients present a progressive decline of these markers until their becoming undetectable in the serum ${ }^{(35)}$. Another hypothesis is the existence of mutating HBV strains which do not express neither antigens nor antibodies in the blood of this population of patients ${ }^{(18,32)}$.

$\mathrm{HCV}$ mean viral load in patients with occult $\mathrm{B}$ infection was lower than in patients without occult infection in this study. MARISCAL et al. ${ }^{(28)}$ suggesting that the presence of HBV inhibits HCV replication. Nevertheless, the findings about HCV viral load in the presence of HBV reported in the literature are conflicting ${ }^{(9,12,13,40)}$.

HCV patients co-infected with occult HBV presented biochemical parameters as well as a greater degree of liver fibrosis which suggest advanced stage of liver disease, as compared with patients solely infected with HCV. This finding is in keeping with the suggestion that HBV co-infection is associated with a more expressive clinical evolution leading faster to end stage liver disease and HCC developments. Nevertheless, in our study it can not be ruled out that the observed differences are due to the longer length of disease, thereby HCV patients are older and presented a longer length of infection as evaluated by the presence of the risk factors of blood transfusion and intravenous drug use.

In conclusion, it can be inferred that occult infection is a fact in our community, particularly in patients with HCV-related HCC. However, this is a cross-sectional study with a relatively small number of patients, therefore large studies are needed to confirm that co-infection could determine a worse progress of chronic liver disease in this population.

Branco F, Mattos AA, Coral GP, Vanderborght B, Santos DE, França P, Alexandre C. Diagnóstico da infecção oculta pelo vírus da hepatite B em pacientes com hepatopatia crônica pelo vírus C. Arq Gastroenterol. 2007;44(1):58-63.

RESUMO - Racional - A prevalência e as conseqüências da infecção oculta pelo VHB em pacientes com infecção crônica pelo VHC permanecem desconhecidas. Objetivo - Avaliar a prevalência da infecção oculta pelo VHB em uma população de pacientes infectados com o VHC e carcinoma hepatocelular. Métodos - Amostras de soro foram testadas para o DNA do VHB por "nested” PCR e análise do tecido hepático utilizando imunoistoquímica de 66 pacientes HBsAg negativos: 26 pacientes com hepatite crônica pelo VHC (grupo 1), 20 com carcinoma hepatocelular relacionado ao VHC (grupo 2) e 20 com marcadores negativos para os vírus das hepatites B e C (grupo controle). Resultados - Infecção oculta pelo VHB foi diagnosticada no tecido hepático de 9/46 (19.5\%) pacientes com infecção pelo VHC. A prevalência foi avaliada nos pacientes com VHC com e sem carcinoma hepatocelular, estando presente em sete (77.7\%) deste último grupo, conferindo $35 \%$ de infecção oculta pelo VHB nos pacientes com carcinoma hepatocelular. Nenhuma amostra de soro foi positiva para o DNA-VHB nos três grupos. Conclusão - A infecção oculta B é freqüentemente detectada no tecido hepático de pacientes infectados com VHC, especialmente nos casos de carcinoma hepatocelular. Entretanto, outros estudos com maior número de pacientes são necessários para confirmar se a co-infecção determina a progressão da doença hepática nesta população.

DESCRITORES - Carcinoma hepatocelular. Vírus da hepatite B. Vírus da hepatite C. Hepatopatias. 


\section{REFERENCES}

1. Acharya SK. Occult hepatitis B infection: the enigmatic virus. Indian J Gastroenterol. 2003;22:121-3

2. Agarwal N, Naik S, Aggarwal R, Singh H, Somani Sk, Kini D. Occult hepatitis B virus infection as a cause of cirrhosis of liver in a region with intermediate endemicity. Indian J Gastroenterol. 2003;22:127-31.

3. Bedossa P, Poynard T. An algorithm for the grading of activity in chronic hepatitis C. The Metavir Cooperative Study Group. Hepatology. 1996;24:289-93.

4. Berasain C, Betes M, Panizo A, Ruiz J, Herrero JI, Civeira MP. Pathological and virological findings in patients with persistent hypertransaminasaemia of unknown aetiology. Gut. 2000;47:429-35.

5. Bowden S, Bartholomeusz A, Locarnini S. Lamivudine resistant occult HBV: implications for public health? J Hepatol. 2003;38:526-8.

6. Brechot C, Degos F, Lugassy C, Thiers V, Zafrani S, Franco D. Hepatitis B virus DNA in patients with chronic liver disease and negative tests for hepatitis B surface antigen. N Engl J Med. 1985;312:270-6.

7. Brechot C, Thiers V, Kremsdorf D, Nalpas B, Pol S, Paterlini-Brechot P. Persisten hepatitis B virus infection in subjects without hepatitis B surface antigen: clinically significant or purely "occult"? Hepatology. 2001;34:194-203.

8. Bruix J, Sherman M, Llovet JM, Beaugrand M, Lencioni R, Burroughs AK. Clinica management of hepatocellular carcinoma. Conclusions of the Barcelona-2000 EASL Conference. European Association for the Study of the Liver. J Hepatol. 2001;35:421-30

9. Cacciola I, Pollicino T, Squadrito G, Cerenzia G, Orlando Me, Raimondo G. Occult hepatitis B virus infection in patients with chronic hepatitis $\mathrm{C}$ liver disease. N Eng J Med. 1999:341:22-6.

10. Chan HL, Tsang SW, Leung NW, Tse CH, Hui Y, Tam JS. Occult HBV infection in cryptogenic liver cirrhosis in an area with high prevalence of HBV infection. Am Gastroenterol. 2002;97:1211-5.

11. Chemin I, Jeantet D, Kay A, Trepo C. Role of silent hepatitis B virus in chronic hepatitis B surface antigen(-) liver disease. Antiviral Res. 2001;52:117-23.

12. Fabris P, Brown D, Tositti G, Bozzola L, Giordani MT, Bevilacqua P. Occult hepatiti $B$ virus infection does not affect liver histology or response to therapy with interferon alpha and ribavirin in intravenous drug users with chronic hepatitis C. J Clin Virol. 2004;29:160-6.

13. Fukuda R, Ishimura N, Niigaki M, Hamamoto S, Satoh S, Tanaka S. Serologically silent hepatitis $\mathrm{B}$ virus coinfection in patients with hepatitis $\mathrm{C}$ virus-associated chronic liver disease: clinical and virological significance. J Med Virol. 1999;58:201-7.

14. Ganem D, Prince AM. Hepatitis B virus infection--natural history and clinical consequences. N Engl J Med. 2004;350:1118-29.

15. Georgiadou SP, Zachou K, Rigopoulou E, Liaskos C, Mina P, Gerovasilis F, Makri E, Dalekos GN. Occult hepatitis B virus infection in greek patients with chronic hepatitis $\mathrm{C}$ and in patients with diverse nonviral hepatic diseases. J Viral Hepat. 2004,11:358-65

16. Giannini E, Ceppa P, Botta F, Fasoli A, Romagnoli P, Ansaldi F. Previous hepatitis $B$ virus infection is associated with worse disease stage and occult hepatitis $B$ virus infection has low prevalence and pathogenicity in hepatitis $\mathrm{C}$ virus-positive patients. Liver Int. 2003;23:12-8

17. Han KH, Hollinger FB, Noonan CA, Solomon H, Klintmalm GB, Genta RM. Southernblot analysis and simultaneous in situ detection of hepatitis B virus-associated DNA and antigens in patients with end-stage liver disease. Hepatology. 1993;18:1032-8.

18. Haushofer AC, Hauer R, Brunner H, Koller U, Trubert-Exinger D, Halbmaye WM. No evidence of hepatitis B virus activity in patients with anti-HBc antibody positivity with or without anti-hepatitis $\mathrm{C}$ virus antibody positivity. J Clin Virol. 2004:29:221-3.

19. Hoofnagle JH, Seeff LB, Bales ZB, Zimmerman HJ. Type B hepatitis afte transfusion with blood containing antibody to hepatitis B core antigen. N Engl J Med. 1978;298:1379-83.

20. Hu KQ. Occult hepatitis B virus infection and its clinical implications. J Viral Hepat. 2002;9:243-57.
21. Kao JH, Chen PJ, Lai MY, Chen DS. Occult hepatitis B virus infection and clinical outcomes of patients with chronic hepatitis C. J Clin Microbiol. 2002;40:4068-71.

22. Kazemi-Shirazi L, Petermann D, Muller C. Hepatitis B virus DNA in sera and liver tissue of HBsAg negative patients with chronic hepatitis C. J Hepatol. 2000;33:785-90

23. Komori M, Yuki N, Nagaoka T, Yamashiro M, Mochizuki K, Kaneko A. Long-term clinical impact of occult hepatitis B virus infection in chronic hepatitis B patients. J Hepatol. 2001;35:798-804.

24. Kubo S, Tamori A, Ohba K, Shuto T, Yamamoto T, Tanaka H. Previous or occult hepatitis B virus infection in hepatitis $\mathrm{C}$ virus-associated hepatocellular carcinoma without hepatic fibrosis. Dig Dis Sci. 2001;46:2408-14.

25. Liver Cancer Study Group of Japan, editors. Classification of primary liver cancer. Tokyo: Kanehara Shuppan; 1997. p.1-22.

26. Llovet JM, Beaugrand M. Hepatocellular carcinoma: present status and future prospects. J Hepatol. 2003;38 Suppl 1:s136-s49.

27. Lyra LGC. Hepatite pelo vírus B. In: Mattos AA, Dantas W, ed. Compêndio de hepatologia. 2.ed. São Paulo: Fundo Editorial Bik, 2001. p.471-87.

28. Mariscal LF, Rodriguez-Inigo E, Bartolome J, Castillo I, Ortiz-Movilla N, Navacerrada C. Hepatitis B infection of the liver in chronic hepatitis $\mathrm{C}$ without detectable hepatitis B virus DNA in serum. J Med Virol. 2004:73:177-86.

29. McOmish F, Yap PL, Dow BC, Follett EA, Seed C, Keller AJ. Geographical distribution of hepatitis $\mathrm{C}$ virus genotypes in blood donors: an international collaborative survey. J Clin Microbiol. 1994;32:884-92.

30. Niigaki M, Fukuda R, Hamamoto S, Ishimura N, Ishihara S, Akagi S. Role of hepatitis B virus in non-B, non-C chronic liver disease: in vitro proliferation and interferon-gamma production of peripheral blood mononuclear cells in response to hepatitis B core antigen and its relation to hepatitis activity. Am J Gastroenterol. 2000;95:239-47.

31. Pal J, Somogyi C, Szmolenszky AA, Szekeres G, Sipos J, Hegedus G. Immunohistochemical assessment and prognostic value of hepatitis $B$ virus $\mathrm{x}$ protein in chronic hepatitis and primary hepatocellular carcinomas using anti-HBxAg monoclonal antibody. Pathol Oncol Res. 2001;7:178-84.

32. Paterlini P, Gerken G, Nakajima E, Terre S, D'Errico A, Grigioni W. Polymerase chain reaction to detect hepatitis B virus DNA and RNA sequences in primary liver cancers from patients negative for hepatitis B surface antigen. N Engl J Med. 1990;323:80-5.

33. Pawlotsky JM, Bouvier-Alias M, Hezode C, Darthuy F, Remire J, Dhumeaux D. Standardization of hepatitis C virus RNA quantification. Hepatology. 2000;32:654-9.

34. Pollicino T, Squadrito G, Cerenzia G, Cacciola I, Raffa G, Crax A. Hepatitis B virus maintains its pro-oncogenic properties in the case of occult HBV infection. Gastroenterology. 2004;126:102-10.

35. Sagnelli E, Coppola N, Scolastico C, Filippini P, Santantonio T, Stroffolini T. Virologic and clinical expressions of reciprocal inhibitory effect of hepatitis B, C, and delta viruses in patients with chronic hepatitis. Hepatology. 2000;32:1106-10.

36. Sagnelli E, Coppola N, Scolastico C, Mogavero Ar, Filippini P, Piccinino F. HCV genotype and "silent" HBV coinfection: two main risk factors for a more severe liver disease. J Med Virol. 2001;64:350-5.

37. Sheu JC, Huang GT, Shih LN, Lee WC, Chou HC, Wang JT. Hepatitis C and B viruses in hepatitis B surface antigen-negative hepatocellular carcinoma. Gastroenterology. 1992;103:1322-7.

38. Shintani Y, Yotsuyanagi H, Moriya K, Fujie H, Tsutsumi T, Takayama T. The significance of hepatitis B virus DNA detected in hepatocellular carcinoma of patients with hepatitis C. Cancer. 2000;88:2478-86.

39. Souto FJD. Distribuição da hepatite B no Brasil: atualização do mapa epidemiológico e proposições para seu controle. GED Gastroenterol Endosc Dig. 1999;18:143-50.

40. Squadrito G, Orlando ME, Pollicino T, Raffa G, Restuccia T, Cacciola I. Virological profiles in patients with chronic hepatitis $\mathrm{C}$ and overt or occult HBV infection. Am J Gastroenterol. 2002;97:1518-23.

41. Torbenson M, Thomas DL. Occult hepatitis B. Lancet Infect Dis. 2002;2:479-86. 